\title{
Estimation of Mating System in the Endangered Aquatic Fern Ceratopteris pteridoides in China Based on AFLP Molecular Marker and Selfing Test: Implications for Conservation
}

\author{
Xiang DONG ${ }^{1 \#}$, Hong LIU ${ }^{1 \#}$, Wei GAO ${ }^{2}$, Rui QIN ${ }^{1}$, \\ Andrew W. GICHIRA ${ }^{3}$, Mo WANG ${ }^{2 *}$, Kuo LIAO ${ }^{3 *}$ \\ ${ }^{1}$ South-Central University for Nationalities, College of Life Sciences, Key Laboratory of State Ethnic Affairs Commission for Biological \\ Technology,Wuhan,China; directx0831@163.com;15102751466@163.com; qin_rui@hotmail.com \\ ${ }^{2}$ Huazhong Agricultural University, College of Plant Science and Technology, Wuhan, \\ China; 504557650@qq.com; wangmo@mail.hzau.cn(*correspondingauthor) \\ ${ }^{3}$ Chinese Academy of Sciences, Wuhan Botanical Garden, Key Laboratory of Aquatic Botany and Watershed Ecology, Wuhan, \\ China; 2484276833@qq.com; liaokuo@wbgcas.cn (*correspondingauthor) \\ "These authors contributed equally to this work
}

\begin{abstract}
Mating system has important implications for the genetic structure and diversity of populations, especially threatened and endangered species. In this study, mating system of the endangered aquatic fern Ceratopteris pteridoides in China was investigated using AFLP markers and selfing test. The results of AFLP analyses showed that the estimate of multilocus outcrossing rate $\left(t_{\mathrm{m}}\right)$ was high at species level $\left(t_{\mathrm{m}}=0.999\right)$, indicating that $C$.pteridoides is a predominant outcrossing species. The small differences between $t_{\mathrm{m}}$ and $t_{\mathrm{s}}(0.136 \pm 0.003)$ at species level showed that there is a low tendency for mating between relatives. The selfing test showed that isolated gametophytes formed the rate of normal sporophytes in three populations (BLH, $\mathrm{ZDH}, \mathrm{WCH}$ ) ranging from $72.9 \%$ to $77.8 \%$ with a mean value of $75.2 \%$, indicating that $C$.pteridoides has a high level of intragametophytic selfing potential. Our investigation found that some of the studied populations of $C$. pteridoides have a prolific capacity for vegetative reproduction (clonal growth). The results revealed that the diploid homosporous pteridophyte C. pteridoides predominantly favors gametophytic crossing with a certain level of inbreeding along with clonal growth. We suggest that mating system of $C$. pteridoides may be adjusted to promote selfing rate in response to factors including the characteristics of hermaphrodite, and colonization events and small extant populations. As a result of the high outcrossing rate of $C$. pteridoides, we recommend that ex situ plantings would be most suitable for enhancing possible intermingling of the different populations thus minimizing inbreeding.
\end{abstract}

Keywords: AFLP; Ceratopteris pteridoides; mating system; outcrossing rates; selfing test

\section{Introduction}

Ceratopteris (Parkerkiaceae) is a genus of ferns that occurs in the New World and Old World tropics and subtropics. Species are either aquatic or sub-aquatic and are typically found in ponds, rivers, and other wet areas such as ditches, taro-patches and rice paddies (Hickok et al., 1995). The genus contains six species (C. cornuta, C. pteridoides, $C$. richardii, C. thalictroides, $C$. froesii, and C. siliquosa), which exhibit one of three mating systems: automixis, autogamy, and xenogamy (Lloyd, 1974a; Hickok et al., 1995). Two species of Ceratopteris (C. thalictroides and C. pteridoides) occur in China (Diao, 1990).
Self-fertilization of a single gametophytes is termed intragametophytic selfing or automixis; Random crosses between gametophytes (sib gametophytes) produced from spores of the same sporophyte has been termed intergametophytic selfing or autogamy and is equivalent to cross-selfing in higher plants; Crosses between gametophytes (non-sib gametophytes) produced from spores of different sporophytes has been termed intergametophytic crossing or xenogamy and is equivalent to crossing in higher plants. The potential for intragametophytic self-fertilization (automixis) renders homosporous pteridophyte unique among plants (Hickok et al., 1995). Ceratopteris exhibits a biphasic life cycle with independent autotrophic haploid and diploid generations. 
Ceratopteris has been used as a model plant for many years in the study of genetics, biochemistry, cell biology, and molecular biology (Hickok et al., 1995).

Ceratopteris pteridoides (Hook.) Hieron. is an annual aquatic floating homosporous fern with diploidy $(2 n=78)$ found principally in Central and South America, Southeastern Asia, Eastern India, and China (Diao, 1990; Hickok et al., 1995; Adjie et al., 2007). The species is restricted in aquatic habitats in ponds, lakes, rivers, ditches and other wetlands (Lloyd, 1974a). In China, it is mainly distributed in central and south regions (Diao, 1990), however, in recent decades, the number and size of $C$. pteridoides populations have rapidly declined mainly due to degeneration of primary habitats, continuous decline in area of wetland coverage and overuse of herbicides (Dong et al., 2007; Tao et al., 2007, 2008; Chen et al., 2010). The species is now endangered and listed in the second category of the Key Protected Wild Plants in China (Yu, 1999). Its plant shape is beautiful, its fronds are heteromorphic leaf including foliage leaf (sterile fronds) and sporophyll (fertile fronds). Therefore, it has high appreciation and is often used as landscape plants (Diao, 1990).

The understanding of the mating system of a species is of fundamental importance for genetic improvement and conservation programmes because it allows the outlining of strategies that optimize the sampling of genetic variability and the adoption of genetic-statistical models appropriate for the estimation of genetic parameters. Information about the mating system, diversity and genetic structure, as well as the spatial distribution of genotypes within populations, is important for the establishment of strategies aimed at the effective conservation of any species (Freitas et al., 2004). An accurate characterization of mating is important for the conservation of the evolutionary potential of natural populations because altered patterns of mating, such as increased inbreeding, may result in future genetic decline and population extinction (Saccheri et al., 1998). For conservation purposes, in recent years, genetic variation among Chinese $C$. pteridoides populations has been investigated using a variety of genetic markers, e.g., random amplified polymorphic DNA (RAPD) (Dong et al., 2010), inter simple sequence repeats (ISSRs) (Dong et al., 2007), and amplified fragment length polymorphism (AFLP) (Chen et al., 2010). From these studies, patterns of low level of within-population genetic diversity and moderate to high levels of among-population genetic differentiation were revealed in Chinese C. pteridoides. Several factors, including clonal growth, dispersal, mating systems, genetic drift, gene flow, have been proposed to explain the genetic variation patterns observed in C. pteridoides. Among these factors, the mating system has been regarded as a major determinant of genetic diversity, genetic structure and gene flow in $C$. pteridoides populations (Chen et al., 2010; Dong et al., 2007, 2010). For example, C.pteridoides is a homosporous fern that possesses two types of inbreeding systems (i.e. intragametophytic and intergametophytic selfing (Klekowski, 1979; Soltis and Soltis, 1990a,b) and, based on RAPD and ISSR analyses, Dong et al. (2007, 2010) suggested that the gametophytic selfing may have played an important role in maintaining low genetic diversity in populations of C. pteridoides while Chen et al. (2010) conducted AFLP analyses and reported that the high level of genetic differentiation among C. pteridoides populations might result from its inbreeding reproductive system. However, none of these studies have intensively investigated the mating system of C.pteridoides. The importance of the mating system of $C$. pteridoides in determining its genetic variation pattern remains largely unknown. Earlier studies on $C$. pteridoides mainly dealt with its distribution, taxonomy, morphology, ecology, and genetics diversity and structure (Hickok et al., 1995; Chen et al., 2010; Dong et al., 2010, 2012, 2014; Cui et al., 2017; Peng et al., 2017).

Investigation on mating system using various molecular markers is of great importance for genetic resource characterization (Loveless, 1992; Pometti et al., 2013). In recent studies, outcrossing rates have been traditionally studied using co-dominant markers such as isozymes and microsatellites due to their high allelic polymorphism (Chaix et al., 2003; Adugna et al., 2013; Sinha et al., 2015; Sharma et al., 2017). However, when microsatellite markers were unavailable, several dominant markers such as RAPD (Gjuric and Smith, 1996), ISSR (Ge and Sun, 1999; Han et al., 2009), and AFLP have been used to estimate outcrossing rates as they are able to produce very large numbers of informative loci without previous genetic information about the genetic system in plant species (Gaiotto et al., 1997; Freitas et al., 2004; Muluvi et al., 2004; Pometti et al., 2013; Sinha et al., 2015; Sharma et al., 2017 ). Amplified fragment length polymorphisms (AFLPs) are easily applied to new species, since DNA sequence knowledge is not required for this technique unlike co-dominant markers such as microsatellites (Vos et al., 1995). AFLP markers are also applicable to DNA of any origin or complexity without prior sequence information, primer synthesis, library construction or the characterization of DNA probes (Vos et al., 1995). Although AFLP markers exhibit dominance (dominant homozygotes and heterozygotes are indiscernible), this lower resolution is compensated for by the easy evaluation of large numbers of loci and highly reproducible results (Mariette et al., 2002). Despite AFLP markers being dominant in most cases, they can detect more variation at the whole genome level than ISSR or RAPD markers, and they may detect variation more efficiently due to large numbers of screened loci that can be readily available and be screened (Chen et al., 2009). The dominant behavior of RAPD, ISSR and AFLP markers provides less information per locus as compared to co-dominant markers (Pometti et al., 2013). This is particularly relevant for applications that require genotype discrimination, as in the case of outcrossing rate estimation (Gaiotto et al., 1997). Ritland and Jain (1981) demonstrated, through simulation studies, that the limitation associated with dominant loci could be readily overcome by multilocus estimation using a large number of dominant markers with intermediate gene frequencies.

The principal aims of this study were to estimate the mating system in natural populations of $C$. pteridoides in China using AFLP markers and a selfing test, and to provide information for both in situ and ex situ conservation and management programs. 
690

\section{Materials and Methods}

\section{AFLP analysis}

\section{Plant material and total DNA extraction}

For the present study 192 individuals of young sterile fronds (sporophytes) were germinated from young spores from ten extant of populations across the species' natural geographic distribution in China. The species had been collected in July and August for three consecutive years (2011 to 2013). Presently there are only ten remaining populations in China which include nine populations in Hubei Province (designated as LGH, LJH, HGH, XLH, $\mathrm{LZH}, \mathrm{ZDH}, \mathrm{BLH}, \mathrm{CHE}$, and WLH) and one population in Jiangxi Province (designated as JCH). All the populations are found in the middle and lower reaches of Yangtze River, which has thousands of shallow lakes most of which are interconnected to the main artery of the river (Fig. 1).

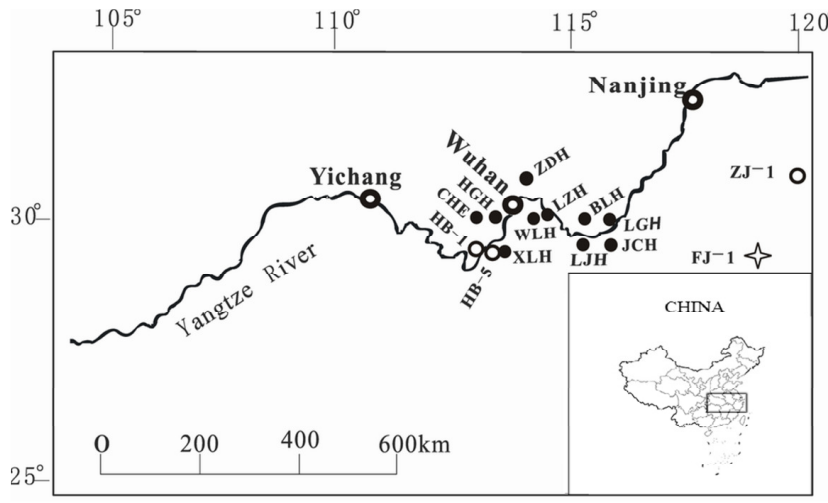

Fig. 1. Distribution of Ceratopteris pteridoides populations sampled in the present study. • Sites of extant populations. $\circ$ Sites of extinct populations. \& Site of population presumed to have disappeared from the previous recorded population. Codes correspond to populations in Table 1.
Three populations (designated as HB-1, HB-5, and ZJ1) which had previously been recorded during fieldwork in the period between 2003 and 2006 (see Dong et al., 2012) had most likely been extirpated and were not found during our field surveys (Fig. 1), only one population (which had been designated as FJ-1) was still in existence. Individuals in each study population were sampled at a minimum distance of $5 \mathrm{~m}$ from each other. Details on collection sites, population size and sampling size are given in (Table 1). Approximately 5-10 g of young sterile fronds were harvested from each plant and immediately dried in a sealed zip lock plastic bag containing about $50 \mathrm{~g}$ of silica gel. Total DNA was extracted from $0.5 \mathrm{~g}$ of silica-dried leaf tissue following the procedure described by Doyle and Doyle (1987). DNA products were resolved electrophoretically on $1 \%$ agarose gels and visualized by staining with ethidium bromide and photographed under ultraviolet light. The concentration and purity of DNA was estimated by Eppendorf biophotometer plus (Eppendorf China Ltd.)

\section{AFLP PCR amplification}

The AFLP analysis was performed as described by Vos et al. (1995). $4 \mu \mathrm{L}(50 \mathrm{ng} / \mu \mathrm{L})$ of total genomic DNA was digested using 3 units of EcoRI and MseI endonuclease mixture (New England Biolabs, Beijing, China) in a total volume of $20 \mu \mathrm{L}$ for $3 \mathrm{hrs}$ at $37^{\circ} \mathrm{C}$. Successful digestion was tested by electrophoresis on $1.5 \%$ agarose gels stained with ethidium bromide and photographed under ultraviolet light. Then, $20 \mu \mathrm{L}$ of ligation solution containing $1 \mu \mathrm{L}$ (5 $\mathrm{pm} / \mu \mathrm{L})$ EcoRI adaptor, $1 \mu \mathrm{L}(50 \mathrm{pm} / \mu \mathrm{L})$ MseI adaptor (Table 2), $10 \mu \mathrm{L}$ of DNA template, and $0.4 \mu \mathrm{L} \mathrm{T} 4(5 \mathrm{U} / \mu \mathrm{L})$ DNA ligase (New England Bio labs) were added to the digests in a total volume of $20 \mu \mathrm{L}$. The ligation mixture was incubated overnight at $22{ }^{\circ} \mathrm{C}$ in a thermocycler. The resulting DNA (template DNA) was then diluted with 1:5 in TE buffer.

Table 1. Geographic distribution, location, habitat, and sample size of Ceratopteris pteridoides populations studied since 2003

\begin{tabular}{|c|c|c|c|c|c|c|c|c|}
\hline $\begin{array}{l}\text { Population } \\
\text { code }\end{array}$ & $\begin{array}{c}\text { Extant/ extinct } \\
\text { population }\end{array}$ & Locality & $\begin{array}{l}\text { Latitude/Longitude } \\
\text { (N/E) }\end{array}$ & $\begin{array}{l}\text { Altitude } \\
(\mathrm{m})\end{array}$ & $\begin{array}{c}\text { Habitats } \\
\left(\text { site area, } \mathrm{km}^{2}\right)^{b}\end{array}$ & $\begin{array}{l}\text { Population } \\
\text { size }\end{array}$ & $\begin{array}{l}\text { Population } \\
\text { area }\left(\mathrm{m}^{2}\right)\end{array}$ & $\begin{array}{c}\text { Sample } \\
\text { size }\end{array}$ \\
\hline LGH & Extant & Longanhu, Hubei & $29^{\circ} 58^{\prime} / 116^{\circ} 01^{\prime}$ & 15 & Lake, 223.22 & $800-1000$ & $1800-2000$ & 28 \\
\hline $\mathrm{XLH}(\mathrm{HB}-2)^{a}$ & Extant & Xilianghu, Hubei & $29^{\circ} 54^{\prime} / 114^{\circ} 02^{\prime}$ & 18 & Fishpond, 0.002 & $1500-2000$ & $1000-1200$ & 29 \\
\hline $\mathrm{LZH}(\mathrm{HB}-3)^{a}$ & Extant & Liangzihu, Hubei & $30^{\circ} 15^{\prime} / 114^{\circ} 34^{\prime}$ & 9 & Lake, 304.30 & $150-200$ & $60-70$ & 31 \\
\hline $\mathrm{LJH}(\mathrm{HB}-4)^{a}$ & Extant & Liangjianhu, Hubei & $29^{\circ} 54^{\prime} / 115^{\circ} 14^{\prime}$ & 26 & Fishpond, 0.006 & $3500-4000$ & $3500-4000$ & 31 \\
\hline $\mathrm{JCH}$ & Extant & Chihu, Jiangxi & $29^{\circ} 47^{\prime} / 115^{\circ} 44^{\prime}$ & 21 & Lake, 68.90 & 40-50 & $20-30$ & 10 \\
\hline BLH & Extant & Balihu, Hubei & $30^{\circ} 07^{\prime} / 115^{\circ} 21^{\prime}$ & 28 & Fishpond, 0.004 & $600-700$ & $700-800$ & 17 \\
\hline $\mathrm{HGH}$ & Extant & Houguanhu, Hubei & $30^{\circ} 30^{\prime} / 114^{\circ} 08^{\prime}$ & 18 & Lake, 43.00 & $100-120$ & $40-45$ & 6 \\
\hline $\mathrm{ZDH}$ & Extant & Zhangduhu, Hubei & $30^{\circ} 36^{\prime} / 114^{\circ} 42^{\prime}$ & 34 & Lake, 40.00 & $3000-4000$ & $2400-2500$ & 20 \\
\hline $\mathrm{CHE}$ & Extant & Chenhu, Hubei & $30^{\circ} 31^{\prime} / 113^{\circ} 82^{\prime}$ & 17.6 & Lake, 200.00 & $1000-1200$ & $2000-2500$ & 13 \\
\hline WLH & Extant & Luhu, Hubei & $30^{\circ} 16^{\prime} / 114^{\circ} 12^{\prime}$ & 23 & Lake, 40.20 & $100-120$ & $8-10$ & 7 \\
\hline HB-1 (HB-1) ${ }^{a}$ & Extinct $^{c}$ & Xiaogang, Hubei & $29^{\circ} 55^{\prime} / 113^{\circ} 13^{\prime}$ & 24 & Ditch, Rice field & & & \\
\hline HB-5 (HB-5) ${ }^{a}$ & Extinct $^{c}$ & Jiayu, Hubei & $29^{\circ} 55^{\prime} / 113^{\circ} 59^{\prime}$ & 19 & Ditch, Rice field & & & \\
\hline ZJ-1 (ZJ-1) ${ }^{a}$ & Extinct $^{c}$ & Huzhou, Zhejiang & $30^{\circ} 51^{\prime} / 120^{\circ} 04^{\prime}$ & 9 & Urban area & & & \\
\hline $\mathrm{FJ}-1(\mathrm{FJ}-1)^{a}$ & Previous recorded ${ }^{c}$ & Wuyishan, Fujian & $27^{\circ} 46^{\prime} / 118^{\circ} 01^{\prime}$ & - & Ditch & & & \\
\hline
\end{tabular}

${ }^{a}$ Population code in braces indicate that of Dong et al. (2012);

${ }^{b}$ Site area: area of each lake or fishpond in present study;

${ }^{c}$ Four populations (HB-1, HB-5, ZJ-1and FJ-1) once were extant populations found in the period from 2003 to 2006 across the natural geographic distribution range of C.pteridoides in Mainland China (see Dong et al. 2012). 
PCR pre-amplification was performed in a $20 \mu \mathrm{L}$ solution containing $2.5 \mu \mathrm{L} 10 \times \mathrm{Taq}$ buffer (TianGen, Beijing, China), $3 \mathrm{mM} \mathrm{MgCl}, 0.5 \mu \mathrm{L}(0.20 \mathrm{mM}) \mathrm{dNTPs}$ (TianGen), EcoR I +0 Primer $(10 \mu \mathrm{M}) 1 \mu \mathrm{L}$, EcoR I +0 Primer $(50 \mu \mathrm{M}) 1 \mu \mathrm{L}$ (Table 2), $0.5 \mu \mathrm{L}(2.5 \mathrm{U} / \mu \mathrm{L})$ of Taq polymerase (TianGen) and $4 \mu \mathrm{L}$ of template DNA for the following thermal profile: an initial melting step at $94^{\circ} \mathrm{C}$ for $3 \mathrm{~min}$, followed by 25 cycles of $94^{\circ} \mathrm{C}$ for $30 \mathrm{~s}, 56^{\circ} \mathrm{C}$ for 1 $\min$ and $72^{\circ} \mathrm{C}$ for $1 \mathrm{~min}$.

For selective PCR amplification, 13 EcoRI + 3/MseI + 3 primer combinations (Table 2) were chosen among 64 sets that were screened for variability, and the 15-fold diluted pre-amplification product was used as template. An aliquot of $4 \mu \mathrm{L}$ diluted pre-amplification DNA was added to $5.5 \mu \mathrm{L}$ of selective amplification cocktail $(20 \mathrm{ng}$ EcoRI +3 primer, 20 ng MseI +3 primer, $0.5 \mu \mathrm{L}$ dNTPs, $2.5 \mu \mathrm{L}$
$10 \times$ Taq buffer (TianGen), $0.5 \mu \mathrm{L}(2.5 \mathrm{U} / \mu \mathrm{L})$ of Taq polymerase, $1.5 \mathrm{mM} \mathrm{MgCl}$ ), and amplified with the following thermal cycle profile: $94^{\circ} \mathrm{C}$ for $3 \mathrm{~min}$, then 13 cycles of $94^{\circ} \mathrm{C}$ for $30 \mathrm{~s}, 65^{\circ} \mathrm{C}$ (decreasing by $0.7^{\circ} \mathrm{C}$ ) for $30 \mathrm{~s}$ and $72{ }^{\circ} \mathrm{C}$ for $1 \mathrm{~min}$, followed by 23 cycles of $94^{\circ} \mathrm{C}$ for $30 \mathrm{~s}$, $56{ }^{\circ} \mathrm{C}$ for $30 \mathrm{~s}$ and $72{ }^{\circ} \mathrm{C}$ for $1 \mathrm{~min}$, then $72{ }^{\circ} \mathrm{C}$ for $5 \mathrm{~min}$. All PCR reactions were performed in a PTC-100TM thermocycler (MJ Research, Inc.).

$7.5 \mu \mathrm{L}$ loading buffer ( $98 \%$ formamide, $10 \mathrm{mM}$ EDTA $(\mathrm{pH} 8.0), 0.25 \%$ bromophenol blue and $0.25 \%$ xylene cyanol) were denatured at $94{ }^{\circ} \mathrm{C}$ for $5 \mathrm{~min}$ and electrophoresis was run in a 6\% denaturing polyacrylamide gel on a $50.5 \times 35 \mathrm{~cm}$ DYCZ-20D DNA Sequencing System (Thermo). Silver staining was conducted as described by Bassam et al. (1991) (Fig. 2). Sizes of selective amplification products were estimated using a 50 bp DNA ladder (TianGen, Beijing, China).

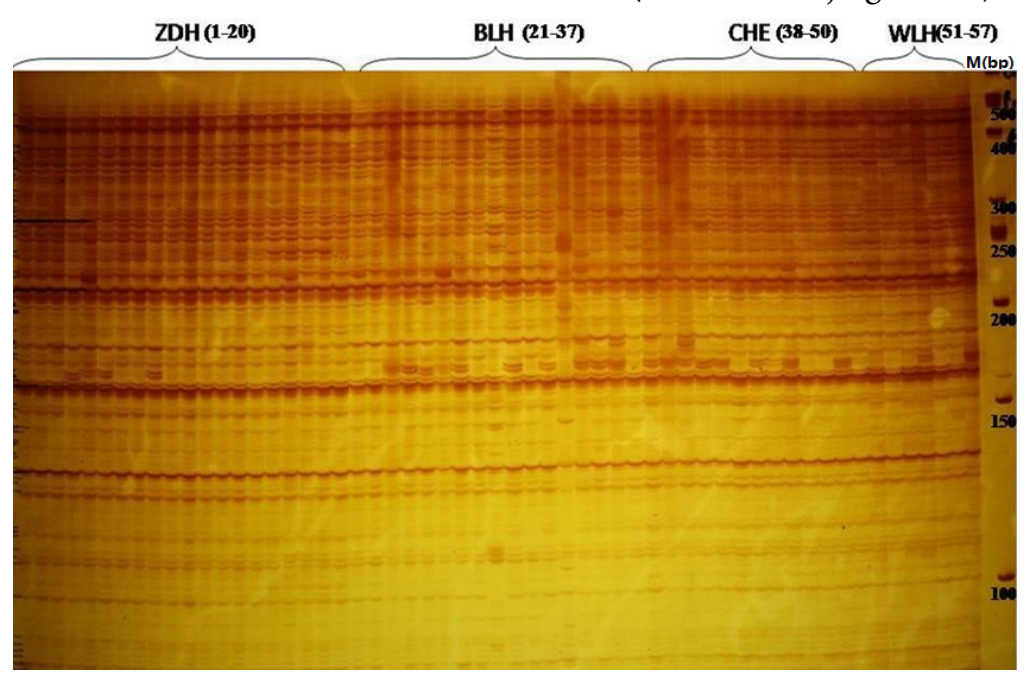

Fig. 2. AFLP amplification products generated from Ceratopteris pteridoides genomic DNA from 57 individuals of four population: ZDH (Lane 1-20), BLH (Lane 21-37), CHE (Lane 38-50), and WLH (Lane 51-57) obtained with E1M2 primer combinations. Marker, $50 \mathrm{bp}$ ladder

Table 2. DNA sequences of AFLP primers, adaptors from each primer combinations of Ceratopteris pteridoides in ten populations studied

\begin{tabular}{|c|c|}
\hline Adaptor & Sequence \\
\hline \multirow[t]{2}{*}{ EcoRI adaptor } & 5'-CTCGTAGACTGCGTACC-3' \\
\hline & 3'-CATCTGACGCATGGTTAA-5' \\
\hline \multirow[t]{2}{*}{ MseI adaptor } & 5’-GACGATGAGTCCTGAG-3' \\
\hline & 3'-TACTCAGGACTCAT-5' \\
\hline \multirow[t]{2}{*}{ EcoRI $+0 /$ MseI +0 primer } & 5'-GACTGCGTACCAATTC-3' (E0) \\
\hline & 5'-GATGAGTCCTGAGTAA-3' (M0) \\
\hline \multirow[t]{13}{*}{ EcoRI $+3 / \mathrm{MseI}+3$ primer } & $\mathrm{E} 1 \times \mathrm{M} 1 \mathrm{E}+\mathrm{AAC} / \mathrm{M}+\mathrm{C} \mathrm{AA}$ \\
\hline & $\mathrm{E} 1 \times \mathrm{M} 2 \mathrm{E}+\mathrm{AAC} / \mathrm{M}+\mathrm{C} \mathrm{AC}$ \\
\hline & $\mathrm{E} 1 \times \mathrm{M} 3 \quad \mathrm{E}+\mathrm{AAC} / \mathrm{M}+\mathrm{C} A G$ \\
\hline & $\mathrm{E} 2 \times \mathrm{M} 6 \mathrm{E}+\mathrm{AAG} / \mathrm{M}+\mathrm{C} \mathrm{TC}$ \\
\hline & $\mathrm{E} 3 \times \mathrm{M} 7 \mathrm{E}+\mathrm{ACA} / \mathrm{M}+\mathrm{C} \mathrm{TG}$ \\
\hline & $\mathrm{E} 4 \times \mathrm{M} 1 \mathrm{E}+\mathrm{ACT} / \mathrm{M}+\mathrm{C} \mathrm{AA}$ \\
\hline & $\mathrm{E} 4 \times \mathrm{M} 3 \mathrm{E}+\mathrm{ACT} / \mathrm{M}+\mathrm{C} A \mathrm{G}$ \\
\hline & $\mathrm{E} 4 \times \mathrm{M} 4 \mathrm{E}+\mathrm{ACT} / \mathrm{M}+\mathrm{CAT}$ \\
\hline & $\mathrm{E} 5 \times \mathrm{M} 7 \mathrm{E}+\mathrm{ACC} / \mathrm{M}+\mathrm{C}$ TG \\
\hline & $\mathrm{E} 6 \times \mathrm{M} 5 \mathrm{E}+\mathrm{ACG} / \mathrm{M}+\mathrm{C}$ TA \\
\hline & $\mathrm{E} 7 \times \mathrm{M} 3 \mathrm{E}+\mathrm{AGC} / \mathrm{M}+\mathrm{C} \mathrm{AG}$ \\
\hline & $\mathrm{E} 8 \times \mathrm{M} 6 \mathrm{E}+\mathrm{AGG} / \mathrm{M}+\mathrm{C} \mathrm{TC}$ \\
\hline & $\mathrm{E} 8 \times \mathrm{M} 7 \mathrm{E}+\mathrm{AGG} / \mathrm{M}+\mathrm{C} \mathrm{TG}$ \\
\hline
\end{tabular}


692

\section{Mating system analyses}

According to the molecular weight (bp), all individuals were scored for the presence (1) or absence (0) of the amplified AFLP fragments (Fig. 2). MLTR 3.4 (Ritland, 2009) programme is based on multilocus mixed-mating model and the estimation procedure of Ritland and Jain (1981) which assumes that progeny are derived from either random mating (outcrossing) or self-fertilization. Using the software, MLTR 3.4 (Ritland, 2009), we calculated the following mating system parameters: estimation of multilocus $\left(t_{\mathrm{m}}\right)$ and single locus $\left(t_{\mathrm{s}}\right)$ out-crossing rates, correlation of outcrossed paternity (rp), correlation of $t_{\mathrm{m}}$ among progeny arrays (rt), and fixation index of maternal parents (F). Biparental inbreeding was also estimated following Ritland (1990) as $t_{\mathrm{m}}-t_{\mathrm{s} \text {. The standard errors for }}$ these parameters were calculated from 1,000 bootstraps with resampling of individuals within families. Standard error was used to determine whether mating parameters were significantly lower than one or greater than zero.

\section{Selfing test of gametophytes}

To determine the genetic potentiality for gametophytic selfing, a selfing test was applied to three spore sources in
BLH, ZDH, CHE populations of C.pteridoides (Table 1). Spores of $C$. pteridoides were collected from the three populations, and refrigerated at $5{ }^{\circ} \mathrm{C}$. Spores were disinfected for $2 \mathrm{~min}$ in $5 \% \mathrm{NaOCl}$. Sterilized spores (about 500-600 number) were sown on agar (Knop's nutrient solution with $1.5 \%$ agar) medium in petri dishes measuring $9 \mathrm{~cm}$ in diameter. The preparation method of Knop's nutrient solution with $1.5 \%$ agar is: adding $1.5 \%$ agar in Knop's nutrient solution, heating until agar was completely melted, sterilization for $20 \mathrm{~min}\left(121^{\circ} \mathrm{C}\right)$. The final packing medium for each petri dish was about $30 \mathrm{ml}$, followed by cooling. All experiments were carried out with three replicate plates for each population at $25 \pm 1{ }^{\circ} \mathrm{C}$ and 80 $85 \%$ humidity. All plates were illuminated with photoperiods of grow light at an intensity of 1500-2000 lux, with $16 \mathrm{~h}$ light and $8 \mathrm{~h}$ dark in an SPRX - 600B intelligent artificial climate box (Shanghai Lang Gan Laboratory Equipment Co., Ltd). Eight days following the sowing of spores, rates of spore germination were recorded under a Jiangnan BM2000 digital microscope (Nanjing Jiangnan Yongxin Optical Co., Ltd). Emergence of rhizoids denotes spore germination in C. pteridoides (Warne and Hickok, 1987). Three horizons for observation in each culture plate

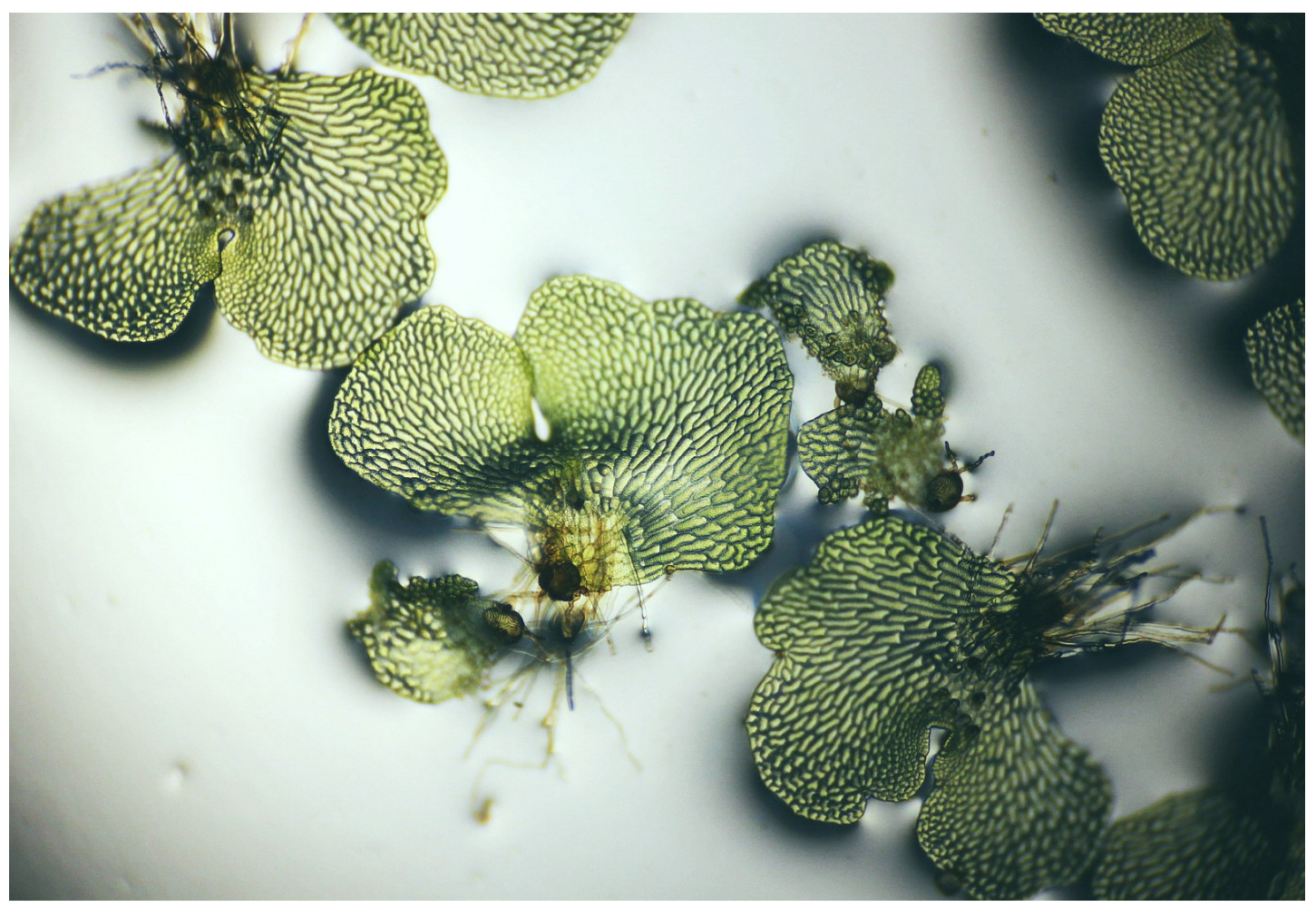

Fig. 3. The large and cordate gametophytes (hermaphroditic gametophytes) and the non-cordate gametophytes of Ceratopteris pteridoides $(\times 400)$

of three replicate plates were selected randomly. Twenty days after sowing, the number of hermaphroditic gametophytes (i.e., those that were large and cordte, and had antheridia as well as archegonia) in each culture plate was recorded (Schedlbauer, 1976) (Fig. 3), and will be used as a statistical analysis of the potentiality for gametophytic selfing, and recorded one times per two-day interval, for a total of three times. Twenty-five days after spore sowing, individual cordate gametophytes (hermaphroditic gametophytes) was isolated onto agar (Knop's nutrient solution with $1.5 \%$ agar) media in 24 holes and $2 \mathrm{~cm}$ diam. petri culture dishes (Fisher Scientific Co., Ltd). Forty-eight hermaphroditic gametophytes from each population were transferred to two culture dishes and were used for isolation sterilized culture. Forty days after spore sowing, the number of normal young sporophytes which isolated gametophytes formed, were recorded for a total of three times. The survival rate of selfing was calculated. All data were analyzed using SPSS 17.0 software (Statistical Product and Survice Solutions 17.0). 


\section{Results}

The estimates of multilocus outcrossing rate $\left(t_{\mathrm{m}}\right)$ and single locus outcrossing rate $\left(t_{s}\right)$ were high in species level and in all populations $\left(t_{\mathrm{m}} \geq 0.999, t_{\mathrm{s}} \geq 0.863\right.$, respectively), indicating that the studied populations of $C$. pteridoides are mostly outcrossers (Table 3 ). The difference between the multilocus and single locus $\left(t_{\mathrm{m}}-t_{\mathrm{s}}\right)$ ranged from 0.079 to 0.136 at species level and within populations, indicating a low tendency for biparental inbreeding. At species level, multilocus correlation of $\mathrm{P}$ estimate (rpm), single locus correlation of $\mathrm{P}$ estimate (rps) and correlation of tm between progeny arrays (rt) were 0.186, 0.108 and 0.097 respectively. The difference (rps - rpm) of estimate was 0.078 . The value of single locus inbreeding coefficient of maternal parents $(\mathrm{F})$ was 0.507 among species, whereas $\mathrm{F}$ values ranged from 0.007 to 0.027 among populations (Table 3).

In all cultures, two types of gametophytes were observed. One type were small, spatulate or amorphous, the other type (called hermaphrodite) were large and cordate gametophytes and had many mature antheridia as well as archegonia, a feature promoting gametophytic selfing (Fig. 3). The rate of cordate gametophytes (hermaphrodite) in three populations was higher, ranging from $83.6 \%$ to $86.8 \%$, with a mean value of $85.6 \%$. Isolated gametophytes formed normal young sporophytes of $C$. pteridoides at a frequency as high as $72.9 \%$ to $77.8 \%$ in three populations $(\mathrm{BLH}, \mathrm{ZDH}, \mathrm{WCH})$, with a mean value of $75.2 \% \pm 2.4 \%$ (Fig. 4, Table 4).
In the study, the phenomenon of vegetative reproduction (clonal growth) was also observed in some of the studied populations of C.pteridoides, such as BLH, LJH, and ZDH (Fig. 5).

\section{Discussion}

In the present study, thirteen combined primers were employed which detected a high number (475) of variable AFLP loci (ranging from 80 to $500 \mathrm{bp}$ ) in C. pteridoides (Fig. 2). The number of polymorphic loci detected was higher than that reported from previous studies in flowering plants such as Eucalyptus urophylla (Gaiotto et al., 1997), Persoonia mollis (Krauss, 2000), Myracrodruon urundeuva (Freitas et al., 2004), Moringa oleifera (Muluvi et al., 2004), Ammopiptanthus nanus (Chen et al., 2009), Acacia visco (Pometti et al., 2013), Jatropha curcas (Sinha et al., 2015), and Pongamia pinnata (Sharma et al., 2017). These highthroughput marker technologies allow for the analysis of a large number of individuals with a large number of markers in a relatively short time, as only a few RAPD primers, ISSR primers or a single AFLP primer pair allow the generation of sufficient markers to obtain a robust estimate of outcrossing rate (Gaiotto et al., 1997; Han et al., 2009; Sinha et al., 2015). The availability of many polymorphic loci provides the opportunity for selecting the most suitable ones depending on the kind of analysis to be conducted. For example, through simulation studies, Ritland and Jain (1981) described the mixed-mating model showing that, more than five dominant marker loci (with $P=0.5$ ) are

Table 3. Mating system parameter of Ceratopteris pteridoides studied in China

\begin{tabular}{ccccccccccccc}
\hline Parameter & $\mathrm{LGH}$ & $\mathrm{XLH}$ & $\mathrm{LJH}$ & $\mathrm{LZH}$ & $\mathrm{JCH}$ & $\mathrm{HGH}$ & ZDH & BLH & CHE & WLH & Species level \\
\hline \multirow{2}{*}{$t_{\mathrm{m}}$} & 1.000 & 1.000 & 1.000 & 1.000 & 1.000 & 1.000 & 1.000 & 1.000 & 1.000 & 1.000 & 0.999 \\
& $(0.000)$ & $(0.000)$ & $(0.000)$ & $(0.000)$ & $(0.000)$ & $(0.000)$ & $(0.000)$ & $(0.000)$ & $(0.000)$ & $(0.000)$ & $(0.003)$ \\
\multirow{2}{*}{$t_{\mathrm{s}}$} & 0.893 & 0.912 & 0.908 & 0.908 & 0.909 & 0.911 & 0.911 & 0.909 & 0.910 & 0.921 & 0.863 \\
& $(0.048)$ & $(0.001)$ & $(0.001)$ & $(0.001)$ & $(0.002)$ & $(0.002)$ & $(0.002)$ & $(0.005)$ & $(0.001)$ & $(0.002)$ & $(0.004)$ \\
& 0.107 & 0.088 & 0.092 & 0.092 & 0.091 & 0.089 & 0.089 & 0.091 & 0.090 & 0.079 & 0.136 \\
$t_{\mathrm{m}}-t_{\mathrm{s}}$ & $(0.048)$ & $(0.001)$ & $(0.001)$ & $(0.001)$ & $(0.002)$ & $(0.001)$ & $(0.002)$ & $(0.005)$ & $(0.000)$ & $(0.002)$ & $(0.003)$ \\
& 0.133 & 0.025 & 0.020 & 0.025 & 0.008 & 0.000 & 0.018 & 0.040 & 0.000 & 0.000 & 0.186 \\
$\mathrm{rp}(\mathrm{m})$ & $(0.044)$ & $(0.012)$ & $(0.000)$ & $(0.009)$ & $(0.004)$ & $(0.000)$ & $(0.010)$ & $(0.025)$ & $(0.000)$ & $(0.000)$ & $(0.020)$ \\
& -0.999 & 0.094 & 0.096 & 0.095 & 0.092 & 0.087 & 0.096 & 0.096 & 0.091 & 0.085 & 0.108 \\
$\mathrm{rp}(\mathrm{s})$ & $(0.112)$ & $(0.000)$ & $(0.000)$ & $(0.000)$ & $(0.001)$ & $(0.001)$ & $(0.001)$ & $(0.001)$ & $(0.000)$ & $(0.001)$ & $(0.001)$ \\
$\mathrm{rp}(\mathrm{s})-$ & -1.132 & 0.069 & 0.070 & 0.070 & 0.084 & 0.087 & 0.078 & 0.056 & 0.091 & 0.085 & -0.078 \\
$\mathrm{rp}(\mathrm{m})$ & $(0.121)$ & $(0.012)$ & $(0.012)$ & $(0.008)$ & $(0.004)$ & $(0.001)$ & $(0.009)$ & $(0.025)$ & $(0.000)$ & $(0.001)$ & $(0.020)$ \\
$\mathrm{rt}$ & 0.110 & 0.110 & 0.109 & 0.110 & 0.110 & 0.110 & 0.109 & 0.110 & 0.110 & 0.110 & 0.097 \\
& $(0.000)$ & $(0.000)$ & $(0.000)$ & $(0.000)$ & $(0.000)$ & $(0.000)$ & $(0.000)$ & $(0.000)$ & $(0.000)$ & $(0.000)$ & $(0.014)$ \\
$\mathrm{F}$ & 0.008 & 0.020 & 0.027 & 0.020 & 0.019 & 0.025 & 0.010 & 0.007 & 0.015 & 0.027 & 0.507 \\
& $(0.006)$ & $(0.002)$ & $(0.002)$ & $(0.002)$ & $(0.001)$ & $(0.000)$ & $(0.001)$ & $(0.001)$ & $(0.000)$ & $(0.000)$ & $(0.011)$ \\
\hline
\end{tabular}

$t_{\mathrm{m}}$, Multilocus outcrossing rate; $t_{\mathrm{s}}$, Single-locus outcrossing rate; $t_{\mathrm{m}} t_{\mathrm{s}}$, Difference of outcrossing rate; $\mathrm{rp}(\mathrm{m})$, The multilocus correlation of paternity; rp $(\mathrm{s})$, The singlelocus correlation of paternity; $\mathrm{rp}(\mathrm{s})-\mathrm{rp}(\mathrm{m})$, Parents correlation; F, Inbreeding coefficient

Table 4. The gametophytes development and selfing test of Ceratopteris pteridoides * (means \pm SD) $(n=3)$

\begin{tabular}{|c|c|c|c|c|c|c|c|}
\hline $\begin{array}{l}\text { Population } \\
\text { code }\end{array}$ & $\begin{array}{l}{ }^{*} \text { Spore germination } \\
\text { rate }(\%)\end{array}$ & $\begin{array}{l}\text { No. of gametophytes } \\
\text { examined }\end{array}$ & $\begin{array}{l}\text { No. of cordate } \\
\text { gametophytes }\end{array}$ & $\begin{array}{c}{ }^{*} \text { Cordate gametophytes } \\
\text { rate }(\%)\end{array}$ & $\begin{array}{l}\text { No. of isolated } \\
\text { gametophytes }\end{array}$ & $\begin{array}{l}\text { No. of normal } \\
\text { sporophytes }\end{array}$ & $\begin{array}{c}{ }^{*} \text { Selfing rate } \\
(\%)\end{array}$ \\
\hline BLH & $38.5(10.0)$ & 159 & 133 & $83.6(3.0)$ & 48 & 35 & $72.9(20.0)$ \\
\hline $\mathrm{ZDH}$ & $43.2(13.0)$ & 143 & 124 & $86.8(2.0)$ & 48 & 36 & $75.0(4.0)$ \\
\hline WCH & $63.8(14.0)$ & 147 & 127 & $86.4(6.0)$ & 48 & 37 & $77.8(1.0)$ \\
\hline Mean & $48.5(13.4)$ & 149.7 & 128 & $85.6(1.7)$ & 48 & 36 & $75.2(2.4)$ \\
\hline
\end{tabular}




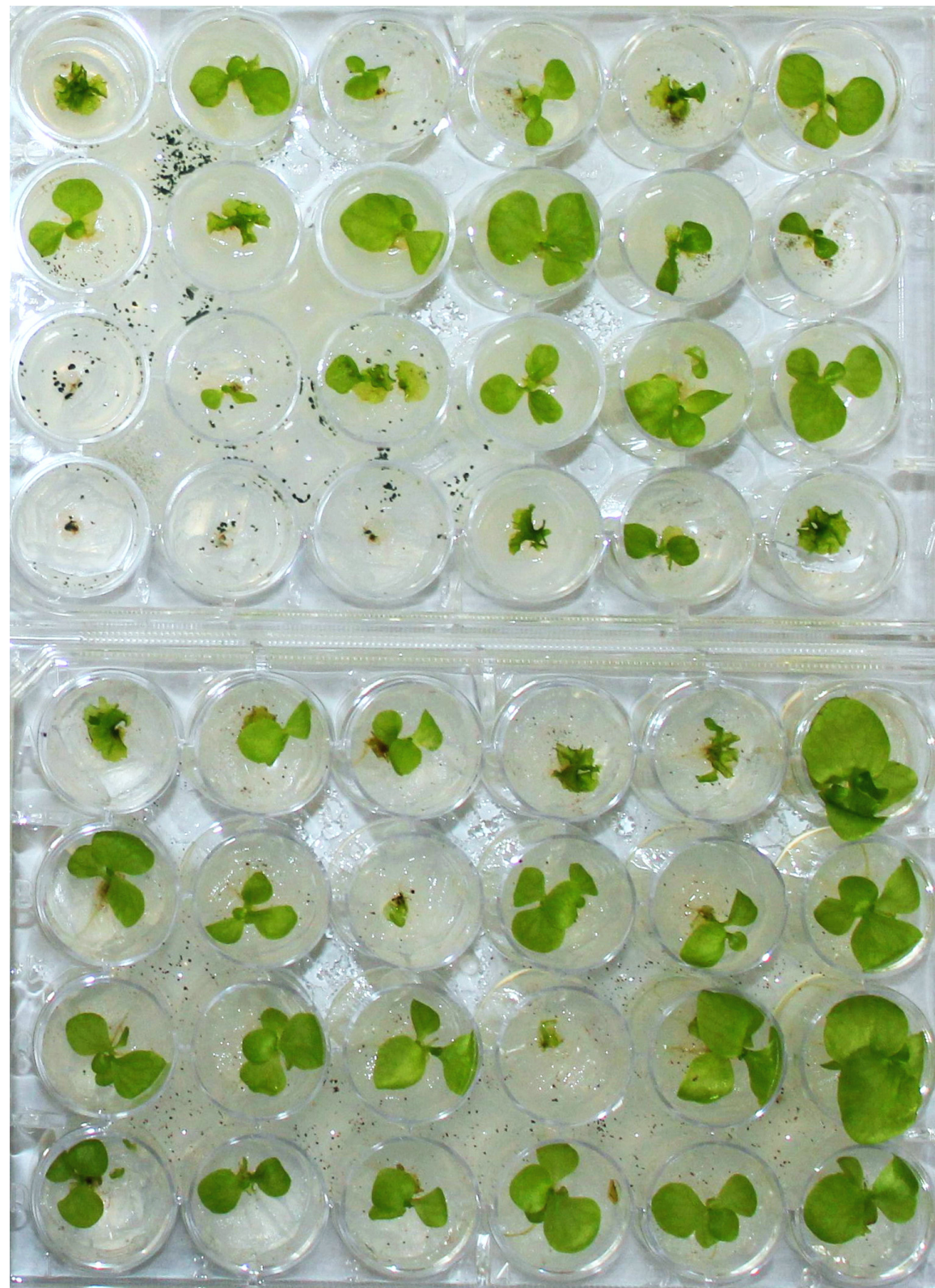

Fig. 4. The part of isolated gametophytes formed normal young sporophytes of Ceratopteris pteridoides

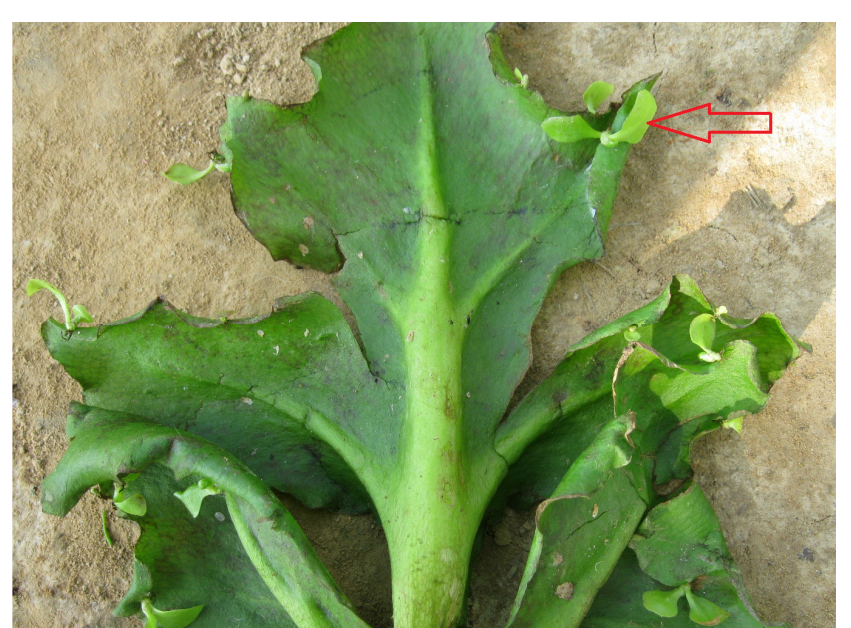

Fig. 5. Clonal growth of Ceratopteris pteridoides (indicated by arrow) necessary to reveal low variance in the estimation of outcrossing rate. They also noted that, dominant loci with allele frequencies close to 0.5 should be preferred to get more accurate estimates of mating system parameters. Our study also highlighted that when dominant markers are applied for outcrossing rate estimation, it is imperative that an adequate screening of primers should be done so as to maximize the probability of amplifying a large number of polymorphic markers in the progeny arrays. The present study indicates that AFLP markers which are dominant with lower information content than co-dominant markers, such as allozyme and SSR markers, are suitable for investigating mating system in $C$. pteridoides.

Previous studies have suggested that diploid species of homosporous pteridophytes have an inclination to gametophytic crossing with some exceptions favouring gametophytic selfing as a derived condition (Haufler, 2002), where polyploid homosporous pteridophytes 
predominantly favour gametophytic selfing (Masuyama and Watano, 1990). Soltis and Soltis (1990a) reported that six diploid species of homosporous pteridophytes in Polystichum showed both outcrossing and low interpopulation divergence. Furthermore, Watano and Masuyama (1991) demonstrated that C. thalictroides (same genus as $C$. pteridoides), a tetraploid homosporous pteridophytes species with $n=77,78$ (Hickok, 1979) is a predominant inbreeder. However, Masuyama et al. (2002) and Liao et al. (2011) suggested that the tetraploid homosporous fern $C$. thalictroides contains at least three cryptic species based on molecular analyses and crossing tests, referred to as the north type $(n=78$ and $2 n=156)$, the south type ( $n=77$ and $2 n=154)$, and the third type ( $n$ $=78$ and $2 n=156$ ). Consideration of the cpDNA sequences, $C L F Y 1$ genotypes of the three cryptic species and CLFYI gene tree in concert suggested that the three cryptic species of $C$. thalictroides had originated through independent allopolyploidization events involving $C$. cornuta and two unknown hypothetical diploid species (Adjie et al., 2007). Sexual reproduction in homosporous pteridophyte occurs on free-living gametophytes that are potentially bisexual. Crossing between gametophytes via spores produced from different sporophytes is termed as intergametophytic crossing or xenogamy (Klekowski, 1979; Soltis and Soltis, 1990b; Hickok et al., 1995). Intergametophytic crossing (xenogamy) is one of three types of mating systems in Ceratopteris (Soltis and Soltis, 1990b). The presence of herbarium specimens with both 16- and 32- spored sporangia and exhibiting mixed features of $C$. pteridoides indicates hybridization occurs naturally in this genus (Lloyd, 1993). In the present study, both multilocus $\left(t_{\mathrm{m}}=0.999 \pm 0.003\right)$ and mean single locus $\left(t_{\mathrm{s}}=0.863 \pm\right.$ 0.004 ) outcrossing rates were relatively high, indicating that C. pteridoides was a predominant outcrossing species. The correlation of $t_{\mathrm{m}}$ within progeny arrays ( $\mathrm{rt}$ ) was low in all populations, showing that there was no difference in outcrossing rates among mother plants (Table 3 ).

Previous studies on gametophyte development have indicated that colonizing species such as $C$. thalictroides which contains at least three cryptic species (Masuyama et al., 2002) may be inbreeders. However, recent studies indicated that the European diploid rock fern Asplenium fontanum, which has high migration capacity, reproduces preferably via outcrossing despite a low frequency of inbreeding that was observed throughout the study area (Hunt et al., 2009; Bystriakova et al., 2014). This is also the case both Pteridium aquilinum and Equisetum arvense which are two colonizers with an outcrossing mating system (Soltis and Soltis, 1990b). Diploid species of C. pteridoides have also been reported to be characterized by annual colonizing ability (Diao, 1990; Hickok et al., 1995; Dong et al., 2010), indicating that the high outcrossing rate reported in the present study is consistent with that of previous studies. However, previous studies have suggested that some ferns may display low outcrossing rates. A few diploid fern species are almost exclusively inbreeding. Diploid species of Botrychium dissectum are characterized by high levels of inbreeding (intragametophytic selfing, 0.95) (McCauley $e t$ al., 1985). The diploid fern $A$. trichomanes subsp. trichomanes is also predominantly an inbreeding taxon (Vogel et al., 1999). Dispersal of free-living gametophytes, floating sporophytes, spores, and moving sperms by water current could play an important role in intergametophytic crossing of C. pteridoides. The current study is the first to report on the outcrossing rate in $C$. pteridoides which is important for optimizing genetic resources conservation and formulating breeding strategies for this species.

The observed low level of inbreeding is expected to occur as a mechanism for reproductive reassurance in diploid, sexually reproducing ferns that reproduce preferably via outcrossing (Ranker and Geiger, 2008; Wubs et al., 2010). Inferences about inbreeding other than selfing (e.g. biparental mating) can be made from the comparison between multi-locus and average single-locus outcrossing rates (Lee et al., 2000). The small difference between $t_{\mathrm{m}}$ and $t_{s}(0.136 \pm 0.003)$ at species level for $C$. pteridoides indicates that there is a low tendency for mating between relatives. It can be deduced that the diploid homosporous pteridophytes C. pteridoides predominantly favors gametophytic crossing with a certain level of inbreeding which includes intragametophytic selfing and intergametophytic selfing.

The sample sizes of AFLP analyses obtained from a population ranged from 6 to 31 owing to reduced population sizes at some sites and the need for caution considering that the species is endangered. It is therefore possible that this could have led to biasness based on small sample sizes at some sites compared to others and hence the need to employ suitable statistical data analyses techniques in comparing populations. The choice of sampling sites was influenced by these considerations. However, the overall trend of the main parameters of mating systems in each population showed that C. pteridoides may favor gametophytic crossing.

A relative higher level of intragametophytic selfing rate within three populations of $C$. pteridoides $(\mathrm{BLH}, \mathrm{ZDH}$, WCH) (the selfing rate values varied from $72.9 \%$ to $77.8 \%$ with a mean value of $75.2 \% \pm 2.4 \%$ ) was detected using the selfing test. The result not only indicated that $C$.pteridoides has a prolific capacity for intragametophytic selfing, but also indicated a high level of intragametophytic selfing potential (Table 4). The result seems to contradict the results of high outcrossing rates evaluated in C.pteridoides based on AFLP molecular markers (Table 3). However, we think that the results of the two evaluation methods are not contradictory. The high level of selfing capacity in C. pteridoides may be explained by several factors, including the characteristics of hermaphrodite, colonization potential, small population, and clonal growth. In homosporous ferns including $C$. pteridoides and $C$. thalictroides, gametophytes have the potential to become male, female or bisexual (Watano and Masuyama, 1991; Hickok et al., 1995; Tao et al., 2007). Gametophytes morphology and sexual status typically varies between individuals and depends both on genetic factors and environmental conditions (Ranker and Houston, 2002). The possibility of producing hermaphroditic gametophytes allows for self-fertilization (intragametophytic selfing) of a single gametophyte (Hickok et al., 1995). Homosporous pteridophytes are unique in having the extreme form of inbreeding known as intragametophytic selfing (self-fertilization), owing to free- 
696

living gameteophtes that are potentially bisexual (Masuyama and Watano, 1990; Soltis and Soltis, 1990b). Intragametophytic selfing facilitates the establishment of a sporophyte from a single spore (Lloyd, 1974b). In addition, intergametophytic selfing may also occur (Soltis and Soltis, $1990 \mathrm{~b})$. C. pteridoides is a gomosporous pteridophytes and has the characteristics of hermaphrodite with mature antheridia and archegonia promoting gametophytic selfing (Fig. 2). Wubs et al. (2010) reported that although Asplenium scolopendrium (a diploid homosporous fern species, $2 n=72$, Tutin et al., 1993) is preferentially outcrossing, when mates are limited it can reproduce through this extreme form of selfing. Therefore, although $C$. pteridoides is preferentially outcrossing, it may reproduce through this extreme form of selfing when mates are limited in order to adapt to the change of living environment and the need to maintain the continuity of offspring. That is to say, isolation gametophytes culture may make the species a preference for intragametophytic selfing (self-fertilization).

This effect is exacerbated by the strong colonizing ability of homosporous ferns resulting from the high dispersibility of their spores and the ability of a single, haploid propagule to become established and reproduce via intragametophytic selfing, which forms populations of genetically identical individuals (Soltis and Soltis, 1990b). Selfing ability is of great importance in the establishment of fern populations following long-distance dispersal (Lott et al., 2003; Wubs et al., 2010) and the advantages of single spore establishment favor selfing genotypes during long-distance colonization in ferns. Selection for selfing genotypes is of particular importance for fern colonization, as very limited distances of gamete dispersal result in strong mate limitation (Peck $e t$ al., 1990). Although some species have mixed mating systems, mating strategies in fern species vary mainly from self fertilization to obligate intergametophytic crossing (Soltis and Soltis, 1990b, 1992). Similarly, a species can alter its mating system from outcrossing to selfing when a few closely related individuals mate and show clonal growth (Innes and Hermanutz, 1998). An example is Solidago sempervirens, which can change its mating system from outcrossing to selfing (Qian et al., 2001). de Groot et al. (2012) suggest that intraspecific variation in mating system may be common, at least among four rare and calcicole ferns species (Asplenium scolopendrium (2n) and A. trichomanes subsp. quadrivalens (4n), Polystichum setiferum $(2 n)$ and $P$. aculeatum $(4 n))$, and that genotypes with high selfing capacity may be present among polyploid as well as diploid ferns. These populations may have established through single-spore colonization, which is only possible for genotypes capable of self-fertilization. Their results support the idea that selection for selfing genotypes may occur during long-distance colonization (Lott et al., 2003; Wubs et al., 2010), even in normally outcrossing, diploid ferns. Intragametophytic selfing has also been reported as a trait that could be linked to invasiveness and successful colonization of new habitats (Lott et al., 2003). Ceratopteris lacks a perennial woody rhizome. Unlike many homosporous ferns $C$. pteridoides being a wide geographic distributions and an annual aquatic weed that forms new populations annually in lakes, ponds, and ditches has annual colonizing ability (Diao, 1990; Dong et al., 2010). This implies that high selfing capacity as a strategy for longdistance dispersal and colonization may be present in diploid $C$. pteridoides. We suggest that $C$. pteridoides may vary the mating strategy for fern population establishment after long-distance dispersal. Similarly, Pangua et al. (2003) reported isolated gametophytes derived from a Spanish population of Polystichum setiferum to be totally incapable of intragametophytic selfing, and therefore described the diploid colonizing species $P$. setiferum as an obligate out crosser. However, results of de Groot et al. (2012) show that a genotype from outside the Kuinderbos in Netherlands was capable of intragametophytic selfing and that genotypes from Kuinderbos populations of $P$. setiferum established by long-distance dispersal showed even higher capacities to selffertilize. Furthermore, the five other diploid fern species reported in the literature to exhibit mixed mating systems also have colonization strategy and geographically wide distributions: Dryopteris expansa (Soltis and Soltis, 1987), Blechnum spicant (Soltis and Soltis, 1988), Hemionitis palmata (Ranker, 1992), Odontosoria chinensis (Ranker et al., 2000) and A. scolopendrium (Wubs et al., 2010). Hence, several diploid fern species exhibit variation in selfing rates among populations and they may rely on temporarily increased selfing rates for their colonization potential (Wubs et al., 2010).

Surveys covering the entire population range of the species in China have reported rapid reduction in numbers and population sizes of C. pteridoides (Dong et al., 2007). Currently, the number of individuals of C. pteridoides at 4 of the 10 remaining natural populations is less than 200 . The main genetic consequences of a small population size are increased genetic drift and inbreeding (Ellstrand and Elam, 1993). Inbreeding and genetic drift caused by small extant populations will inevitably lead to decreased genetic variability (Ellstrand and Elam, 1993; Huang et al.2001).

Clonal growth and mating system may also influence population growth and genetic diversity of aquatic plants (Waycott, 1995; Qian et al., 2001). C. pteridoides has a prolific capacity for vegetative reproduction (clonal growth) by means of numerous marginal leaf buds that rapidly develop into plantlets (Diao, 1990; Dong et al., 2010). In the present study, the phenomenon was also observed in some of the studied populations of C.pteridoides, such as BLH, LJH, and ZDH (Fig. 5). Diao (1990) reported that in China, sexual reproduction in $C$. thalictroides and $C$. pteridoides accounted for a greater proportion of population growth than clonal propagation. Extensive cloning can lead to reduced reproductive potential of outcrossing species and increased inbreeding rates in self-compatible plants (Frankham et al., 2002). It is therefore probable that clonal growth also increased inbreeding rates within populations of C.pteridoides.

Thus, although $C$. pteridiodes predominantly favors gametophytic crossing, we suggest that this species may alter its mating strategy. Factors that may promote selfing of this species include the characteristics of hermaphrodite, colonization events and small populations. In the isolated culture, mating system of the species is unique in having the extreme form of inbreeding known as intragametophytic selfing (self-fertilization). In natural populations, especially large natural populations, C. pteridoides predominantly 
favors gametophytic crossing. However, in large natural populations, it is not clear that the species takes what mechanism to increase the rate of outcrossing. The result of mating system based on two kinds of evaluation methods (AFLP markers and a selfing test of isolation gametophyte cultivation) is not contradictory.

Proper estimates of the outcrossing rates are often needed for planning breeding programmes, conservation and management of tropical trees (Loveless, 1992; Pometti et al., 2013). Scientific understanding of the mating system in $C$. pteridoides will provide critical base-line information for developing sustainable management strategies. In our study, the high outcrossing rate of $C$. pteridoides indicated that ex situ plantings would result in possible intermingling among the different populations, thus minimizing inbreeding, while enhancing gene flow and increasing their effective size. Considering the fact that only ten extant populations were found and these had relatively low levels of genetic diversity within populations (Dong et al., 2007, 2010; Chen et al., 2010), preservation of any one population would be insufficient to protect all the variation in the species. Therefore all populations throughout the entire range of the species should be considered in formulating an appropriate conservation strategy for the species. Great attention should be paid to the several small populations such as JCH, HGH, LZH, and WLH to ensure their inclusion in situ and ex situ conservation. In attempts aimed at recovering populations of endangered species, including $C$. pteridoides and avoiding rapid genetic loss within populations, habitat conservation that allows a large number of individuals to survive will be of critical importance. In our studies of $C$. pteridiodes in China in a period of more than ten years, we have severally found that the many habitats of $C$. pteridoides have been detrimentally affected by anthropogenic activities (Dong et al., 2010). Tao et al. (2008) reported that herbicides bensulfuron-methyl and quinclorac inhibit gametophyte growth and sex organ differentiation in C. pteridoides at low concentrations, in turn affecting sexual reproduction. There is need to focus on protecting more habitats of C. pteridoides in China. In particular attention should be given to the reduction of effects of human activities, especially from excessive aquaculture and run-off water from human and industrial effluents that pollute water bodies inhabited by this endangered aquatic fern species.

\section{Conclusions}

Our results revealed that the diploid homosporous fern C. pteridoides predominantly favors gametophytic crossing with a certain level of inbreeding (including both intragametophytic and intergametophytic selfing) along with clonal growth. $C$. pteridoides may vary the mating strategy in some extent. Factors, including the characteristics of hermaphrodite and colonization events and small extant populations, may serve to promote selfing rate in $C$. pteridoides. The high outcrossing rate of $C$. pteridoides indicated that ex situ plantings would result in possible intermingling among the different populations and minimizing inbreeding.

\section{Acknowledgements}

We are grateful to Muchuku John Kamau for linguistic help. The work was supported by the National Natural Science Foundation of China (grant number 31170341, 31200170) and the National Species Fund on Basic Research of Science and Technology of China (grant number 2014FY110100).

\section{References}

Adjie B, Masuyama S, Ishikawa H, Watano Y (2007). Independent origins of tetraploid cryptic species in the fern Ceratopteris thalictroides. Journal of Plant Research 120:129-138.

Adugna A, Sweeney PM, Bekele E (2013). Estimation of in situ mating systems in wild sorghum (Sorghum bicolor (L.) Moench) in Ethiopia using SSR-based progeny array data: implications for the spread of crop genes into the wild. Journal of Genetics 92:3-10.

Bassam BJ, Caetano-Anolles G, Gresshoff PM (1991). Fast and sensitive silver staining of DNA in polyacrylamide gels. Analytical Biochemistry 196:80-83.

Bystriakova N, Ansell SW, Russell SJ, Grundmann M, Vogel JC, Schneider $\mathrm{H}$ (2014). Present, past and future of the European rock fern Asplenium fontanum: combining distribution modelling and population genetics to study the effect of climate change on geographic range and genetic diversity. Annals of Botany 113:453-465.

Chaix G, Gerber S, Razafimaharo V, Vigneron P, Verhaegen D, Hamon S (2003). Gene flow estimation with microsatellites in a Malagasy seed orchard of Eucalyptus grandis. Theoretical andAppliedGenetics 107:705-712.

Chen GQ, Huang HW, Crawford DJ, Pan BR, Ge XJ (2009). Mating system and genetic diversity of a rare desert legume Ammopiptanthus nanus (Leguminosae). Journal of Systematics and Evolution 47:57-66.

Chen YY, Han QX, Cheng Y, Li ZZ, Li W (2010). Genetic variation and clonal diversity of the endangered aquatic fern Ceratopteris pteridoides as revealed by AFLP analysis. Biochemical Systematics andEcology 38:1129-1136.

Cui NX, Wu J, Dai YR, Li Z, Cheng SP (2017). Influence of nitrogen loading and flooding on seedling emergence and recruitment from a seed bank in Chaohu Lake Basin, China. Environmental Science and Pollution Research 24:22688-22697.

de Groot GA, Verduyn B, Wubs ERJ, Erkens RHJ, During HJ (2012). Inter-and intraspecific variation in fern mating systems after longdistance colonization: the importance of selfing. BMC Plant Biology 12:3.

DiaoZS (1990). Aquatic weeds in China. Chongqing Press, Chongqing.

Dong YH, Chen JM, Gituru RW, Wang QF (2007). Gene flow in populations of the endangered aquatic fern Ceratopteris pteridoides in China as revealed by ISSR markers. Aquatic Botany 87:69-74.

Dong YH, Robert GW, Wang QF (2010). Genetic variation and gene flow in the endangered aquatic fern Ceratopteris pteridoides in China, and conservation implication. Annales Botanici Fennici 47:3444.

Dong YH, Wang QF, Robert GW (2012). Effect of habitat modification 
on the distribution of the endangered aquatic fern Ceratopteris pteridoides (Parkeriaceae) in China, and conservation strategy. American Fern Journal 102:136-146.

Dong YH, Gao W, Wei N, Li SH (2014). Comparison of species diversity of Ceratopteris pteridoides community at different habitats in China. Journal of Wuhan University 60 (4):388-344.

Doyle JJ, Doyle JL (1987). A rapid DNA isolation method for small quantities of fresh tissues. Phytochemical Bulletin 19:11-15.

Ellstrand NC, Elam DR (1993). Population genetic consequences of small population size: implications for plant conservation. Annual Review of Ecology and Systematics 24:217-242.

Frankham R, Ballou JD, Briscoe DA (2002). Introduction to conservation genetics. Cambridge University Press, Cambridge.

Freitas MLM, Sebbenn AM, Moraes MLT, Lemos EGM (2004). Mating system of a population of Myracrodruon urundeuva F. F. \& M. F. Allemão using the fAFLP molecular marker. Geneticsand Molecular Biology 27:425-431.

Gaiotto FA, Bramucci M, Grattapagia D (1997). Estimation of outcrossing rate in a breeding population of Eucalyptus urophylla with dominant RAPD and AFLP markers. Theoretical and Applied Genetics 95:842849.

Gjuric R, Smith SR (1996). Identification of cross-pollinated and selfpollinated progeny in Alfalfa through RAPD nulliplex loci analysis. CropScience 36:389-393.

Ge XJ, Sun M (1999). Reproductive biology and genetic diversity of a cryptoviviparous mangrove Aegiceras corniculatum (Myrsinaceae) using allozyme and intersimple sequence repeat (ISSR) analysis. MolecularEcology 8:2061-2069.

Han YC, Teng CZ, Wahiti GR, Zhou MQ, Hu ZL, Song YC (2009). Mating system and genetic diversity in natural populations of Nelumbo nucifera (Nelumbonaceae) detected by ISSR markers. Plant Systematics andEvolution 277:13-20.

Haufler CH (2002). Homospory 2002: An odyssey of progress in pteridophyte genetics and evolutionary biology. Bioscience 52:10811093.

Hickok LG (1979). Cytological relationships between three diploid species of the fern genus Ceratopteris. Canadian Journal of Botany 55:16601667.

Hickok LG, Warne TR, Fribourg RS (1995). The biology of the fern Ceratopteris and its use as a model system. International Journal of Molecular Sciences 156:332-345.

Huang JC, Wang WK, Hong KH, Chiang TY (2001). Population differentiation and phylogeography of Hygrophila pogonocalyx based on RAPDs fingerprints. Aquatic Botany 70:269-280.

Hunt HV, Ansell SW, Russell S, Schneider H, Vogel JC (2009). Genetic diversity and phylogeography in two diploid ferns, Asplenium fontanum subsp. fontanum and $A$. petrarchae subsp. bivalens, in the western Mediterranean. Molecular Ecology 18:4940-4954.

Innes J, Hermanutz IA (1998). The matingsystem and genetic structure in a disjunct population of the seaside goldenrod Solidago sempervirens $\mathrm{L}$. (Asteraceae). Heredity 61:447-454.

Klekowski EJ (1979). The genetics and reproductive biology of ferns. In: Dyer AF (Ed). The experimental biology of ferns. Academic Press,
London pp 133-170.

Krauss SL (2000). Patterns of mating in Persoonia mollis (Proteaceae) revealed by an analysis of paternity using AFLP: implications for conservation. Australian Journal of Botany 48:349-356.

Lee SL, Wickneswari R, Mahani MC, Zakri AH (2000). Mating system parameters in a tropical tree species, Shorea leprosula Miq. (Dipterocarpaceae), from Malaysian lowland dipterocarp forest. Biotropica 32:693-702.

Liao YY, Yang XY, Motley T J, Chen JM, Wang QF (2011). Phylogeographic analysis reveals two cryptic species of the endangered fern Ceratopteris thalictroides (L.) Brongn. (Parkeriaceae) in China. Conservation Genetics 12:1357-1365.

Lloyd RM (1974a). Systematics of the genus Ceratopteris Brongn. (Parkeriaceae) II. Taxonomy. Brittonia26:139-160.

Lloyd RM (1974b). Reproductive biology and evolution in the Pteridophyta. Annals of the Missouri Botanical Garden 61:318-331.

Lloyd RM (1993). Parkeriaceae Hooker, water fern family. In: Editorial Committee (Eds). Flora of North America North of Mexico, Vol 2. Pteridophytes and gymnosperms, Oxford University Press, New York pp 119-121.

Lott MS, Volin JC, Pemberton RW, Austin DF (2003). The reproductive biology of the invasive ferns Lygodium microphyllum and L.japonicum (Schizaeaceae): implications for invasive potential. American Journal of Botany 90:11441152.

Loveless MD (1992). Isozyme variation in tropical trees: patterns of genetic organization. New Forests 6:67-94.

Mariette S, LeCorre V, Austerlitz F, Kremer A (2002). Sampling within the genome for measuring within-population diversity: trade-offs between markers. MolecularEcology 11:1145-1156.

Masuyama S, Watano Y (1990). Trends for inbreeding in polyploid pteriodphytes. Plant Species Biology 5:13-17.

Masuyama S, Yatabe Y, Murakami N, Watano Y (2002). Cryptic species in the fern Ceratopteris thalictroides (L.) Brongn. (Parkeriaceae). I. Molecular analyses and crossing tests. Journal of Plant Research 115:8797.

McCauley DE, Whittier DP, Reilly LM (1985). Inbreeding and the rate of self-fertilization in a grape fern, Botrychium dissectum. American Journal ofBotany 72:1978-1981.

Muluvi GM, Sprent JI, Odee D, Powell W (2004). Estimates of outcrossing rates in Moringa oleifera using Amplified fragment length polymorphism (AFLP). African Journal of Biotechnology 3:146-151.

Pangua E, Quintanilla LG, Sancho A, Pajarón S (2003). A comparative study of the gametophytic generation in the Polystichum aculeatum group (Pteridophyta). International Journal of MolecularSciences 164(2):295-303.

Peck JH, Peck CJ, Farrar DR (1990). Influences of life history attributes on formation of local and distant fern populations. American Fern Journal $80: 126-142$.

Peng Y, Liu L, Li GS (2017). Effects of auxin and its transport inhibitors on spore germination in Ceratopteris pteridoides. Journal of Jishou University (Natural Science Edition) 38(3):55-59.

Pometti CL, Bessega CF, Vilardi JC, Saidman BO (2013). Comparison of mating system parameters and genetic structure in three natural 
scenarios of Acacia visco (Leguminosae, Mimosoideae). Plant Systematics andEvolution 299:761-771.

Qian W, Ge S, Hong DY (2001). Genetic variation within and among populations of a wild rice Oryza granulata from China detected by RAPD and ISSR markers. Theoretical and Applied Genetics 102:440449.

Ranker TA (1992). Genetic diversity, mating systems, and interpopulation gene flow in neotropical Hemionitis palmata L. (Adiantaceae). Heredity 69:175-183.

Ranker TA, Gemmill CEC, Trapp PG (2000). Microevolutionary patterns and processes of the native Hawaiian colonizing fern Odontosoria chinensis (Lindsaeaceae). Evolution 54:828-839.

RankerTA,Houston HA (2002). Is gametophyte sexuality in the laboratory a good predictor of sexuality in nature? American Fern Journal 92:112118.

Ranker TA, Geiger JMO (2008). Population genetics. In: Ranker TA, Haufler $\mathrm{CH}$ (Eds). Biology and evolution of ferns and lycophytes. Cambridge University Press, Cambridge pp 107-133.

Ritland K, Jain S (1981). A model for the estimation of outcrossing rate and gene frequencies using $n$ independent loci. Heredity 47:35-52.

Ritland K (1990). A series of FORTRAN computer programs for estimating plant matingsystems. Journal of Heredity 81:235-237.

Ritland K (2009). Multilocus mating system program MLTR Version 3.4. University of British Columbia, Canada. Available at: http://genetics.forestry.ubc.ca/ritland/programs.html

Saccheri I, Kuussaari M, Kankare M, Vikman P, Fortelius W, Hanski I (1998). Inbreeding and extinction in a butterfly metapopulation. Nature 392:491-494.

Schedlbauer MD (1976). Fern gametophyte development: controls of dimorphism in Ceratopteris thalictroides. American Fern Journal 63:1080-1087.

Sharma SS, Islam MA, Negi MS, Tripathi SB (2017). Estimation of outcrossing rates in biodiesel species Pongamia pinnata based on AFLP and microsatellite markers. National Academy Science Letters 40(2):105-108.

Sinha P, Islam MA, Negi MS, Tripathi SB (2015). Estimation of outcrossing rates in interspecific backcross plants of Jatropha curcas (L.) using AFLP and SSR markers. Physiology and MolecularBiology ofPlants 21(4):605-609.

Soltis DE, Soltis PS (1987). Breeding system of the fern Dryopteris expansa: evidencefor mixed mating. American Fern Journal 74:504509.
Soltis PS, Soltis DE (1988) Genetic variation and population structure in the fern Blechnum spicant (Blechnaceae) from western North America. American Fern Journal 75:37-44.

Soltis PS, Soltis DE (1990a) Genetic variation within and among populations of ferns. American Fern Journal 80:161-172.

Soltis PS, Soltis DE (1990b) Evolution of inbreeding and outcrossing in ferns and fern-allies. PlantSpecies Biology 5:1-11.

Soltis DE, Soltis PS (1992). The distribution of selfing rates in homosporous ferns. American Fern Journal 79:97-100.

Tao L, Yin LY, Li W (2007). Effects of herbicide quindorac on sexual reproduction of Ceratopteris pteridoides. Journal of Wuhan Botanical Research 25:601-604.

Tao L, Yin LY, Li W (2008). Effects of herbicide bensulfuron-methyl on gametophyte development and sex organ differentiation in Ceratopteris pteridoides. Journal of PlantEcology 32:408-412.

Tutin TG, Heywood VH, Burges NA, Valentine SH, Moore DM (1993). Flora Europaea. Vol. 1. Psilotaceae to Platanaceae, 2nd edn. Cambridge University Press, Cambridge.

Vogel JC, Rumsey FJ, Schneller JJ, Barrett JA, Gibby M (1999). Where are the glacial refugia in Europe? Evidence from pteridophytes. Biological Journal of the Llinnean Society 66:23-37.

Vos P, Hogers R, Bleeker M, Reijans M, van de Lee T, Hornes M,... Zabezu M (1995). AFLP: a new technique for DNA fingerprinting. Nucleic Acids Research 23:4407-4414.

Warne T, Hickok L (1987). (2-Chloroethyl) phosphoric acid p promotes germination of immature spores of Ceratopteris richardii Brongn. Plant Physiology 83:723-725.

Watano Y, Masuyama S (1991). Inbreeding in natual populations of the annual polyploidy fern Ceratopteris thalictroides (Parkeriaceae). Systematic Botany 16:705-714.

Waycott M (1995). Assessment of genetic variation and clonality in the seagrass Posidonia australis using RAPD and allozyme analysis. MarineEcology-Progress Series 116:289-295.

Wubs ERJ, de Groot GA, During HJ, Vogel JC, Grundmann M, Bremer P, Schneider H (2010). Mixed mating system in the fern Asplenium scolopendrium: implications for colonization potential. Annals of Botany (Oxford) 106:583-590.

Yu YF (1999). A milestone of wild plant conservation in China. Plants 5:311. 